\title{
Liquid Chromatographic Analysis of Coal Surface Properties
}

$D O E / P C / 91283 \cdots-12$

DA92 040537

Quarterly Progress Report

For the Feriod September - December 1991

\author{
R. C. Rwon \\ Cherical Ingineering Departwent: \\ School of Engineering and Architecture \\ Tuskegee University \\ Tuskegee, Alabana 36088
}

\section{DISCLAIMER}

This report was preparad as an account of work sponsoted by an agency of the United Siates

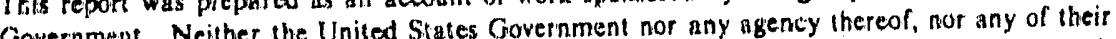
crnployees, makes any warranty, express or implied, or assumes any legal liability or responsibility for the tuccuracy, completeness, or usefulness of any information, apparatur, product, of process disclosed, or represents that its use would not infringe privately owned rights. Refers ence hercir to any specific commercial producl, process, or service by trade name, tradernark. manufacturer, or otherwise does not necessarily' constitute or imply its endorsement, reconmendation, of favoring by the Unised States Government of any agency thereaf. The views and opinions of authors expressed berein do not necessarily state or reflest those of the United States Government or any agency thereor.

\section{Prepared for the United States Department of Energy under.}

the Contract No, DE-FG2,2-91PC91283 
CONTENTS

Page

I. Statement of work $\ldots \ldots \ldots \ldots \ldots \ldots \ldots \ldots \ldots \ldots \ldots \ldots \ldots \ldots$

II. Project status $\ldots \ldots \ldots \ldots \ldots \ldots \ldots \ldots \ldots \ldots \ldots \ldots \ldots \ldots$ 
I. Statement of Work

The main obfectives of this proposed research are to refine further the inverse liquid chromatography technique for the study of surface properties of raw coals, treated coals and coal minerals in water, to evaluate relatively surface properties of raw coals, treated coals and coal minerals by inverse liquid chromatography, and to evaluate flotability of various treated coals in confunction with surface properties of coals.

Cosls such as Pittsburgh seall cosl, Illinois \#6 cosl, Wyodak coal are chosen as representatives of high-rank bituminous cosl, high volatile bituminous cosl and subbituminous coal, respectively, Coal winerals such as pyrite and dolomite are chosen as representative coal minerals.

Alcohols such as methanol, ethanol, isopropanol, isobutano1, tert-butanol, heptano1, 1-hexadecanol, 2-methyl-pentanol, 4-methy1-2-penthanol (methylisobutyl carbinol), n-octanol, s-octanol, and cyclohexanol as probe compounds are utilizer to evaluate hydrophilicity of coals and coal minerals.

N-alkanes such as hexane, heptane and octane, and stearic acid are employed as probe compounds to evaluate hydrophobicity of coals and coal minerals. Aromatic compounds such as benzene and toluene as probe compounds are used to examine aromaticity of coal surface. Aromatic acids such as o-cresol m-cresol, p-cresol, phenol and B-naphthol are used to detect aromatic acidic sites of coal surface.

Bydrophilicity, hydrophobicity and aromaticity of surfaces for either raw coals or treated coals in water are relatively determined by evaluating both equilibrium physical/chemical sdsorption and dymamic adsorption of probe compounds on various raw coals and treated coals to compare affinities of coals for water. 
Dynamic adsorption experiments will be conducted in a batch reactor equipped with a magnetic stirrer. A given amount of raw/treated cosls or coal minerals, and given ant of an aqueous solution with a known concentration of a probe compound are introduced in a batch reactor at room temperature. Concentrations of probe compounds at various contact durations are determined with a HPLC, equipped with a RI detector.

Equilibrium adsorption experiments are performed in either a packed column at room temperature. A given amount of coals or coal minerals is pacted in an empty HPLC column. An aqueous solution of a probe compound of interest is passec through the bed packed in the column. Concentrations of the effluent from the colum are evaluated with the RI detector.

\section{Project Status}

The environmental checklist was approved by the U.S. Department of Energy gs well as the Alabama State (see the attached correspondence). The notice of Energy RD\&D project was completed (see the attached form). The equipment for this research project were selected according to descriptions and prices of these equipment . 
$\because \quad$.

ATTACHMENT I

Environmental Impact Letter 


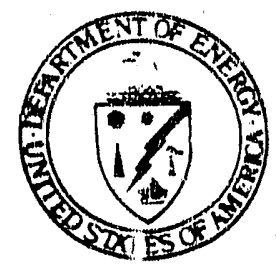

\section{Department of Energy \\ Pittsburgh Energy Technology Center \\ P.O. Box 10940 \\ Pittsburgh, Pennsylvania 15236.0940}

september 3, 1991

Mr. F. Lawrence Oaks

state Historic Preservation officer

Alabama Hietorical Commision

725 Monroe street

Montgomery, AL 36130

Dear Mr. Oaks:

The U.S. Department of Energy (DOE), Pittaburgh Energy Technology Center (PETC) is sponsoring a project ent: " Properties." This project will bo carried out by Turkegee University in Tuskegee, Alabama. As part of agency coordination and contultation responsibilities, and to comply with the provisions of the National of this project on cultural and historie properties.

A brief description of the project is provided in Attachment $A$; a site plan for the project is provided in Attachment B. Based on the fact that the project will be conducted within an existing facility, the DOE concludes that there will be no fefect on historic properties.

We would appreciate your written concurrence on this determination. Should you require additional information, please contact me at (412) 892-6290.

sincerely,

Prober C. Enlemer

Robert C. Dolence

office of Project Management

Attachments

cc:

$\rightarrow$ K. C. Kwon

G. Staata, RM-40

L. Losenzi, DI-04

J. Murphy, PM-50 
Attachment $A$

Tuskegee University - "Iiquid Chromatographic Analysis of Coal surface Properties", University Coal Research Program Grant No. DE-FG22-91PC91283

\section{Profect Description}

This 36-month project will involve laboratory-scale research using about 100 grams/day of research materials. It will involve liquld chromatographic analyses of fine-cosl surfaces. The environment will not be impacted by this study because it is a non-destructive analysis procedure with no reaction products reaulting and therefore no reaction products emitted.

The main objective of the project is to evaluate surface properties of coal using a liquid chromatographic techniçue involving varloug probe sompounds. Various coals will be treated involving samples of raw and cleaned. Affinities of either aromatics or aromatio acida for chosen coal whll be investigated in the presence of either surfactants or depressants to study effects of surfactants on their affinities for chooen coals.

The proposed action will develop an ingight into the surface propertiea of raw and cleaned coal for assisting the formulation of refined cleaning procedurea. These new procedures will enable coal to be burned that contatns less harmful constituents (ash, sulfur, and possibly trace elements) that pollute the atmoaphere.

\section{Envifonmental Effects}

\section{Construction}

The proposed research effort is based on small-scale laboratory study conducted in an exiating facility at the Tuskegee University in Tugkegee, Alabama. There will be no excavation or earthmoying as a result of this action. Therefore, there will be no impact on wildlife habitats, wetlands, or archaeological sites.

\section{operstion}

significant adverse environmental impacts will not resilt from the proposed action. The laboratory procedures to be used in this research effor: are not radiation-procedures; are confined to a relatively minor floor area of the total laboratory (about 12 by 12 feet); and amounts of liquids used are in the milliliter range (about 100 grams (or milliliteru/dayl) over the 3-year span of the contract. About 2-3 grams of coal sample will be used per day. Normal dirposal facilities will be utilized ard pose no hazardous and/or toxic waste problems. 


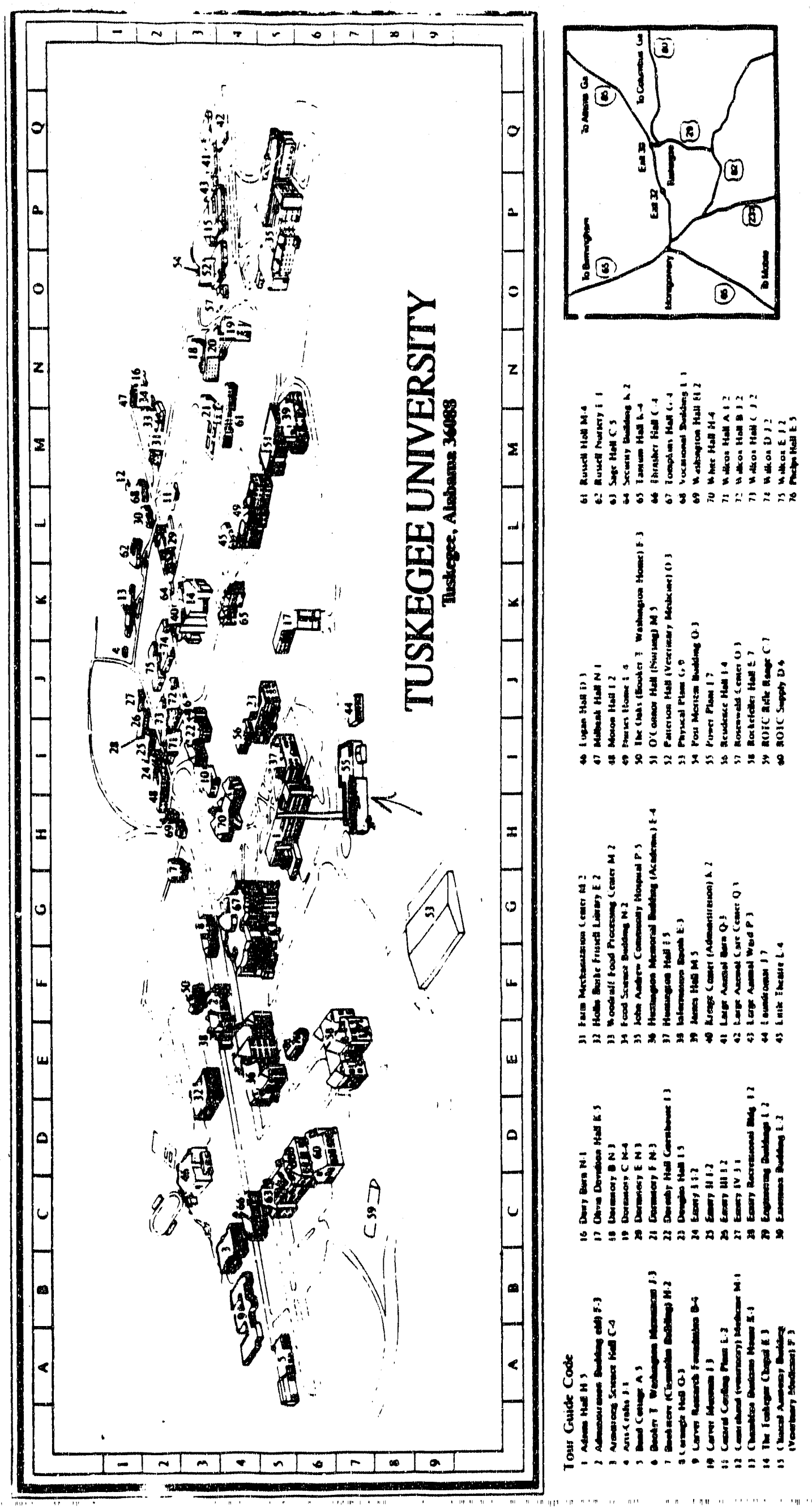


Technical
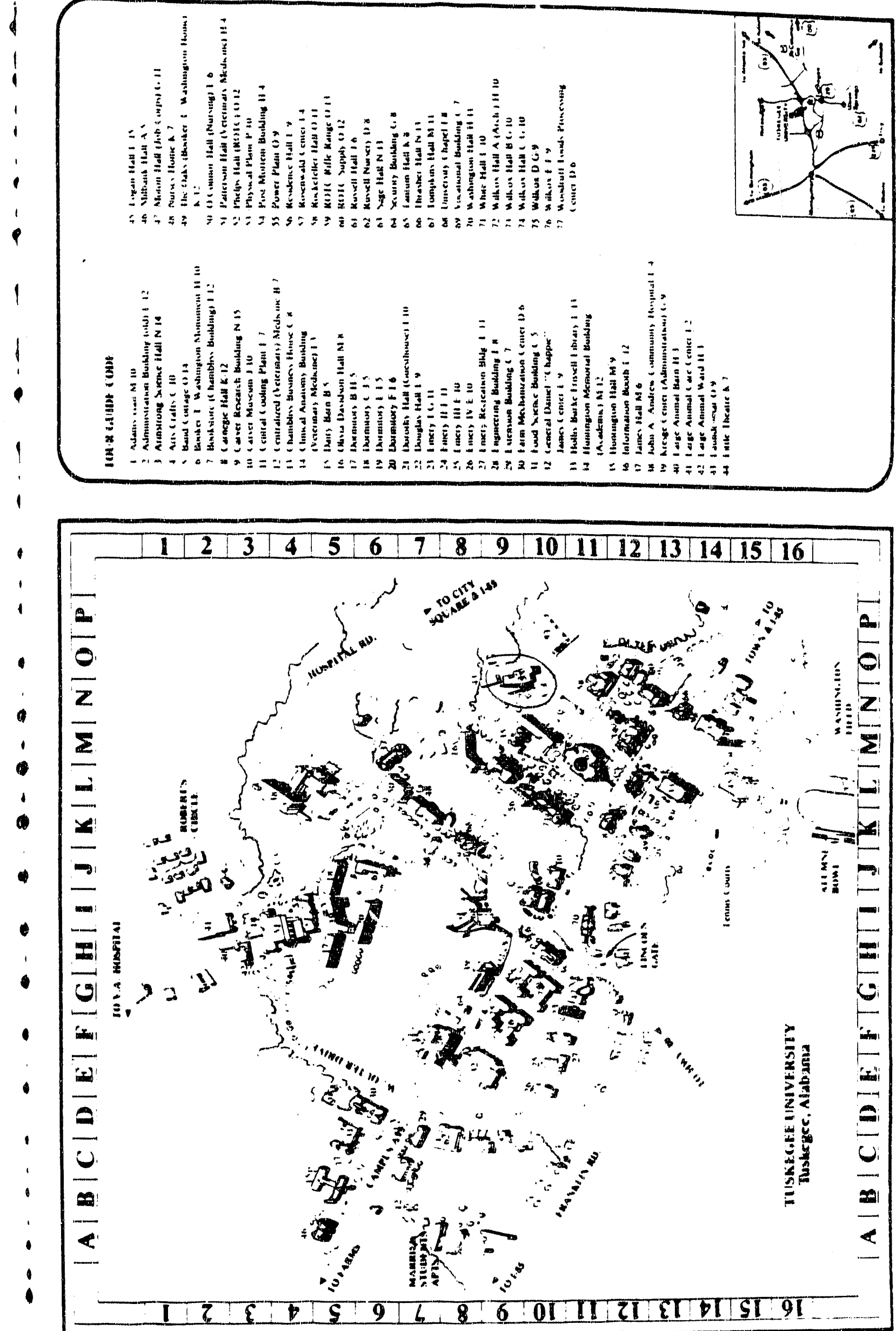

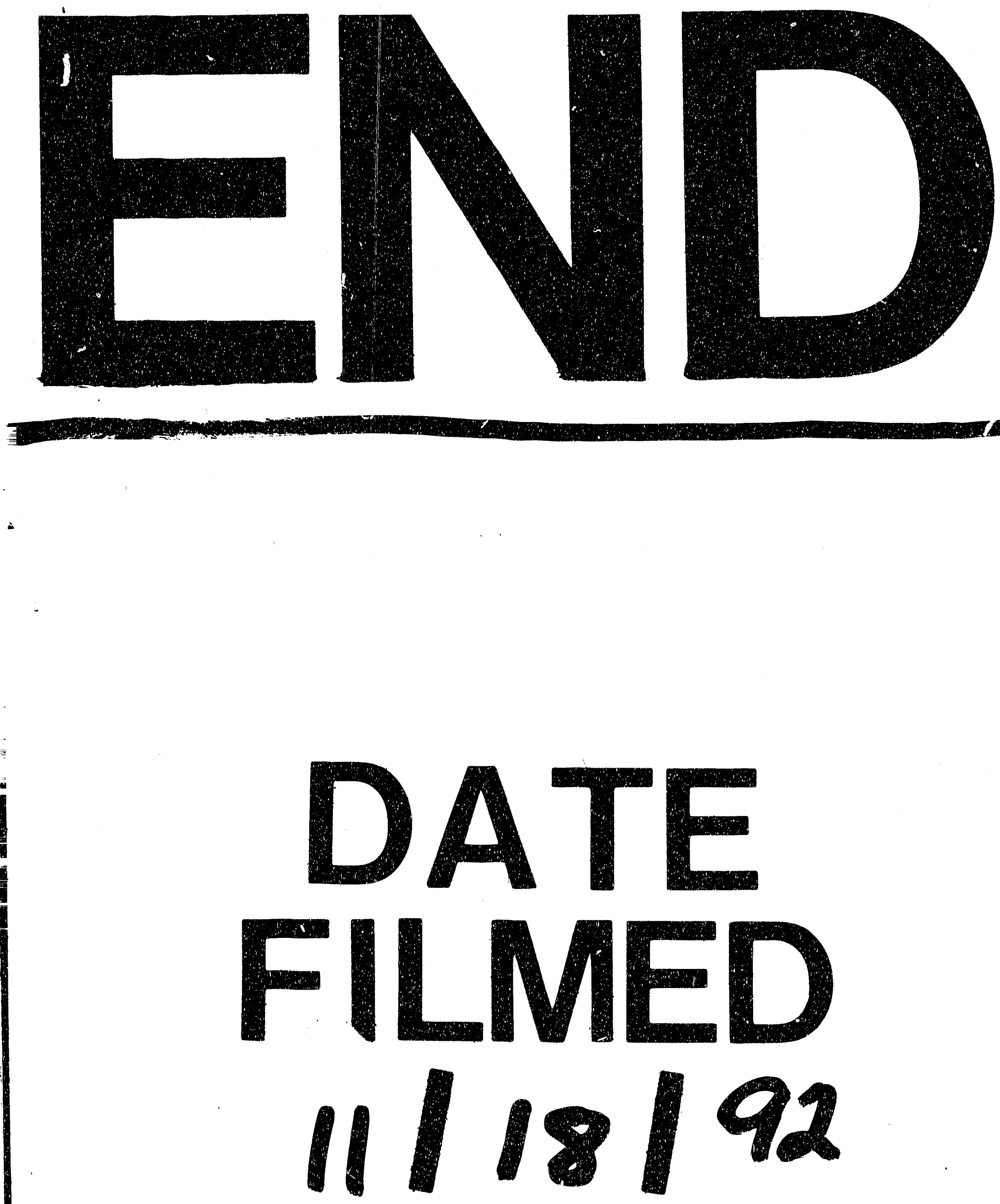


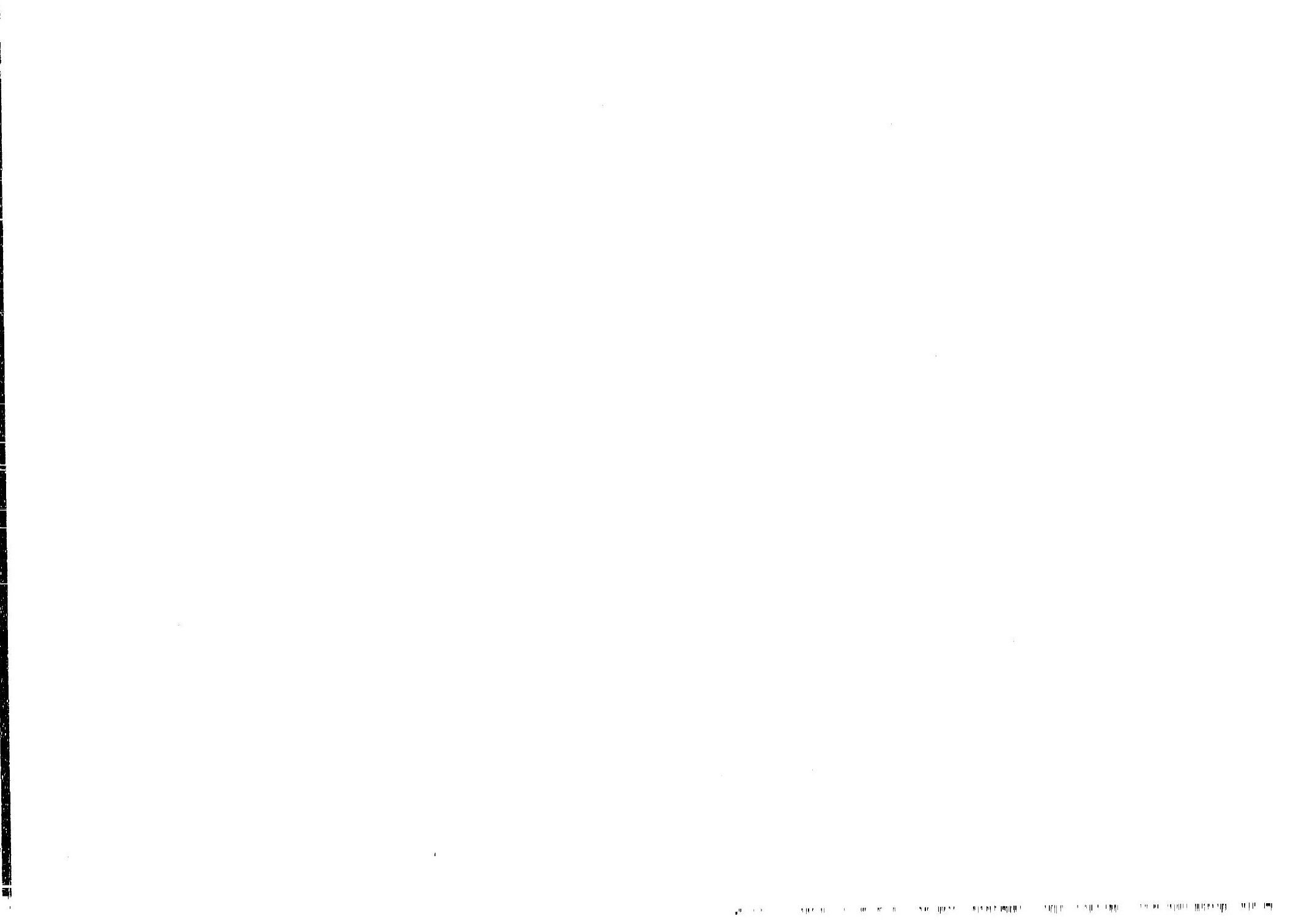

